\title{
The Effect of Homogenization and Chemical Compositions of 6005 and 6082 Aluminium Alloys on the Cold Forming Process
}

\author{
Havva Demirpolat ${ }^{1 *}$, Seracettin $\mathrm{Akd}_{1}{ }^{2}$, Bülent $\mathrm{Alkan}^{3}$ \\ 1* Selçuk Üniversitesi, Faculty of Teknoloji, Departmant of Mechanical Engineering, Konya, Türkiye,(ORCID: 0000-0002-2981-9867), hdemirpolat@ selcuk.edu.tr \\ ${ }^{2}$ Akdı Mühendislik, İnnopark Teknoloji Geliştirme Bölgesi, Konya, Turkey, (ORCID: 0000-0002-4814-8982), info@ akdimuhendislik.com \\ ${ }^{3}$ Hitit University, Faculty of Engineering, Departmant of Metallurgy and Materials, Çorum, Turkey, (ORCID: 0000-0003-1048-7986), bulentalkan@hitit.edu.tr
}

(1st International Conference on Applied Engineering and Natural Sciences ICAENS 2021, November 1-3, 2021)

(DOI: 10.31590/ejosat.973063)

ATIF/REFERENCE: Demirpolat, H., Akd1, S., Alkan, B. (2021). The Effect of Homogenization and Chemical Compositions of 6005 and 6082 Aluminium Alloys on the Cold Forming Process. European Journal of Science and Technology, (28), 16-20.

\begin{abstract}
Aluminium alloys are one of the most preferred materials in the automotive industry due to their properties such as easy recyclability, easy formability and high specific strength. 6XXX alloys are especially used in automotive parts due to their good mechanical properties such as high corrosion and high fatigue strength.6XXX alloys are cast as billets or ingots by continuous casting methods. The alloys are subjected to homogenization heat treatment and shaped by extrusion, respectively. During extrusion forming, fibers are formed in the profile in the direction of extrusion. It has been observed that the coarseness of these fibers formed in the extrusion process causes undesirable deep tears, cracks and distortion of surface when the aluminium profiles are subjected to the cold forming process. In this study, cracking and surface deformations are completely eliminated that occurred after cold forming thanks to alloy improvements and heat treatment. The cold forming process is modeled with the finite element method in order to control surface deformations due to cold forming. Alloy enhancement and homogenization heat treatment applied samples were subjected to cold forming process. As a result, the homogenization heat treatment applied to the part produced from the alloy with improved chemical composition eliminated the deep tears, residual stresses and invisible heterogeneities in the grain structure.
\end{abstract}

Keywords: Cold forming, Aluminium alloy, 6082, 6005, Heat treatment

\section{5 ve 6082 Alüminyum Alaşımlarının Homojenizasyon ve Kimyasal Bileşimlerinin Soğuk Şekillendirmeye Etkisi}

$\ddot{O} \mathbf{z}$

Alüminyum alaşımları kolay geri dönüştürülebilirlik, kolay şekillendirilebilirlik ve yüksek özgül mukavemet gibi özelliklerinden dolayı otomotiv endüstrisinde en çok tercih edilen malzemelerdendir. 6XXX alaşımları, yüksek korozyon ve yüksek yorulma mukavemeti gibi iyi mekanik özelliklerinden dolayı özellikle otomotiv parçalarında kullanılmaktadır.6XXX alaşımları sürekli döküm yöntemleriyle biyet veya ingot olarak dökülmektedir. Alaşımlar sırasıyla homojenizasyon ısıl işlemine tabi tutulur ve ekstrüzyonla şekillendirilir. Ekstrüzyon şekillendirme sırasında, ekstrüzyon yönünde lifler oluşabilmektedir ve ekstrüzyon işleminde oluşan bu liflerin kabalığının, alüminyum profiller soğuk şekillendirme işlemine tabi tutulduğunda istenmeyen derin yırtılmalara, çatlaklara ve yüzeyde bozulmalara neden olduğu gözlemlenmiştir. Bu çalışmada, alaşımdaki kimyasal bileşimlerin ve uygulanan homojenizasyon 1sıl işleminin soğuk şekillendirme sonrası oluşan çatlama ve yüzey deformasyonlarına etkisi gözlenmiştir. Soğuk şekillendirmeden kaynaklanan yüzey deformasyonlarını kontrol etmek için soğuk şekillendirme işlemi sonlu elemanlar yöntemi ile modellenmiştir. Alaşım geliştirme ve homojenizasyon ısıl işlemi uygulanan numuneler soğuk şekillendirme işlemine tabi tutulmuştur. Sonuç olarak, geliştirilmiş kimyasal bileşime sahip alaşımdan üretilen parçaya uygulanan homojenizasyon 1sıl işlemi, tane yapısındaki derin yırtıkları, artık gerilmeleri ve gözle görülmeyen heterojenlikleri ortadan kaldırmıştır.

Anahtar Kelimeler: Soğuk Şekillendirme, Alüminyum alaşımlar, 6082, 6005, Isıl İşlem

*Sorumlu Yazar:hdemirpolat@ selcuk.edu.tr 


\section{Introduction}

An important goal of automobile industry is developing light and high-strength alloys without sacrificing safety and comfort. In addition to being light and durable aluminium alloys have highly important useful area for fuel saving in the automotive industry. Apart from design changes in vehicles, the only method that can reduce weight is to use lighter materials in automobile manufacturing. AA $6 \mathrm{XXX}$ or Al-Mg-Si aluminium alloys series are widely used in the automotive industry thanks to their lightness, good corrosion resistance, high strength and good formability. 6082 and 6005 alloys are especially used as a wrought alloys in extrusion and forging. [1]. AA 6082 and AA6005 are aluminium alloys which $\beta$-Al5FeSi, $\alpha$-Al12 $(\mathrm{FexMn}(1-\mathrm{x})) 3 \mathrm{Si}$ phases and $\mathrm{Mg} 2 \mathrm{Si}$ particles formed during solidification on extrusion process. Also this phases effected on extrusion process, the surface quality of the material and workability.[2,3] The melting of the $\beta$-Al5FeSi phase during extrusion causes poor surface quality. Phase transformation of $\beta$ Al5FeSi into $\alpha$-Al12 (FexMn(1-x))3Si particles with higher $\mathrm{Fe} / \mathrm{Si}$ ratio occurs with the homogenization process. [4-8,10] Thanks to the homogenization process it is enabled to reduce the $\mathrm{Mg}$ and $\mathrm{Si}$ concentrations local melting risks during rolling or extrusion process. In addition, the spheroidization of $\alpha$ particles that will give better extrusion properties and surface finish takes place with homogenization. [3,4,7,9,10]. When AlMgSi alloys contains precipitating elements such as manganese, chromium, and zirconium that phases precipitate at high temperature (approximately $500^{\circ} \mathrm{C}$ ) can be formed during the homogenization process. These precipitate ensure the preservation of the fibrous structure during the extrusion process. This infrastructure causes the increase in strength to be higher with the subsequent aging process. [11]

If aluminium alloys are exposed to thermo-mechanical effects, the grain structure changes physically. First grain structure recrystallizes and then grain growths. Mainly, recrystallizes mechanism is based on amount of $\beta$-AlFeSi phases in solution. For this reason, the process should be designed for the desired high strength, to prevent partial crystallization or to give a fine thread-like grain structure throughout. [12]. Much more $\mathrm{Si}$ used than $\mathrm{Mg}$ can bind to increase the aging hardening capacity in the 6082 alloy. Also Mn used to control the grain structure. In this case, the strength depends on the composition and process conditions [10-13]. The most important factor in material structure is grain size. As the grain size gets thinner, fracture toughness and ductility increase. Generally, deformation rate is proportional to ductility. At low temperature affects deformation hardening, while at high temperatures the rate of deformation is effective. As a result of deformation; recovery, recrystallization and grain growth mechanism occurs. The event that occurs during the annealing process as a result of cold deformation is recovery and recrystallization. The recrystallization, which starts with temperature and deformation energy at the grain boundaries, covers the whole structure with deformation and temperature, and then the structure recrystallizes creates grain growth at the annealing temperature. [13]

\section{Material and Method}

\subsection{Experimental method}

The chemical compositions of the aluminium profiles used in the study is given in Table 1. Microstructure analysis was performed to compare the fibers formed in the extrusion direction. Samples were taken from its vertical sections. Samples were prepared with standard metallographic methods. Polished with $3 \mu \mathrm{m}$ diamond suspension solution and then finished colloidal silica. They were etched with $\% 0.5 \mathrm{HF}$ acid etching solution. Microstructural features of the samples were obtained in Fig1. Samples were prepared with standard metallographic methods for macro etching by taking horizontal and vertical sections from AA6005 and AA6082 aluminium profiles. They were etched with acid solution which compound HCL, HF, HNO3 and pure water. Both of horizontal and vertical sections for AA6005 and AA6082 macrostructure images of are given in Figure 2.a-d The macrostructure analysis of the part from AA6082 alloy and applied homogenization was performed but no significant difference was observed in the macro structure before and after homogenization. For this reason the macro structure image of the homogenized AA6082 is not given. Finally, cold forming process was applied to the parts with the help of a hydraulic press as seen in Fig 3. Homogenization process was applied to only 6082 alloy. Homogenization process was applied at $580^{\circ} \mathrm{C}$ and conducted for 8 hours in protherm furnace. The samples were cooled with air conditions. 6005 alloy cannot homogenized due to its low strength as seen in Table2.

Table 1. The chemical composition of the aluminium profiles (wt.\%)

\begin{tabular}{|c|c|c|c|c|c|c|}
\hline Alloy & $\begin{array}{l}\% \\
\mathrm{Si}\end{array}$ & $\begin{array}{l}\% \\
\text { Mn }\end{array}$ & $\begin{array}{l}\% \\
\mathrm{Cu}\end{array}$ & $\begin{array}{l}\% \\
\mathrm{Mg}\end{array}$ & $\begin{array}{l}\% \\
\mathrm{Cr}\end{array}$ & $\begin{array}{l}\% \\
\mathrm{Fe}\end{array}$ \\
\hline AA 6005 & 0.78 & 0.06 & 0.06 & 0.61 & 0.05 & 0.20 \\
\hline AA 6082 & 1.03 & 0.61 & 0.07 & 0.76 & 0.20 & 0.21 \\
\hline
\end{tabular}

Table 2. Hardness comparison of materials made of AA6082 alloy and AA6082 alloy

\begin{tabular}{|c|c|}
\hline Material & $\begin{array}{c}\text { Brinell } \\
\text { Hardness }(\mathrm{HB})\end{array}$ \\
\hline AA6005 & 36,46 \\
\hline AA6082 & 97,63 \\
\hline $\begin{array}{c}\text { AA6082+Homogenizatio } \\
\text { n }\end{array}$ & 45,13 \\
\hline
\end{tabular}




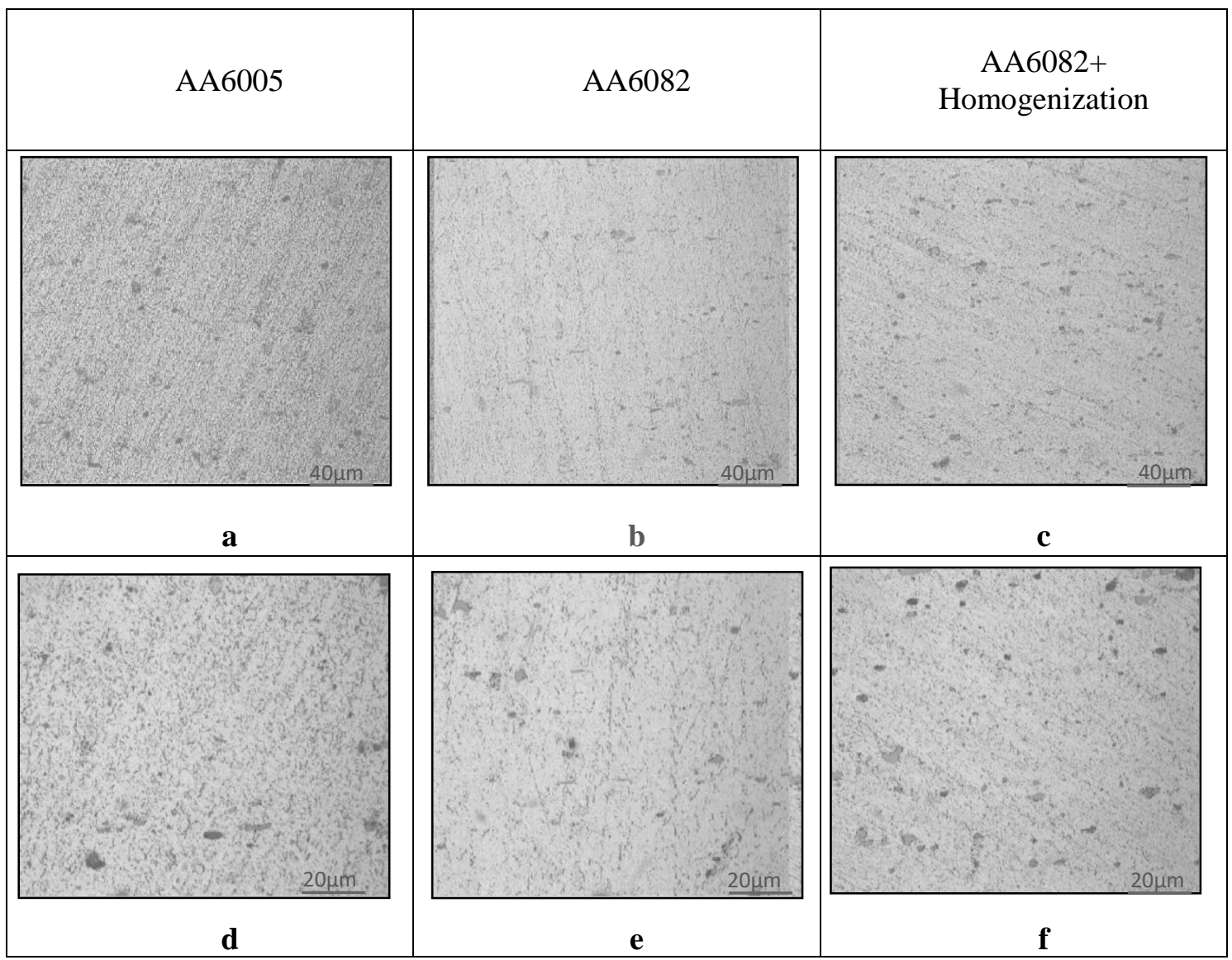

Figure1. Microstructural features of samples

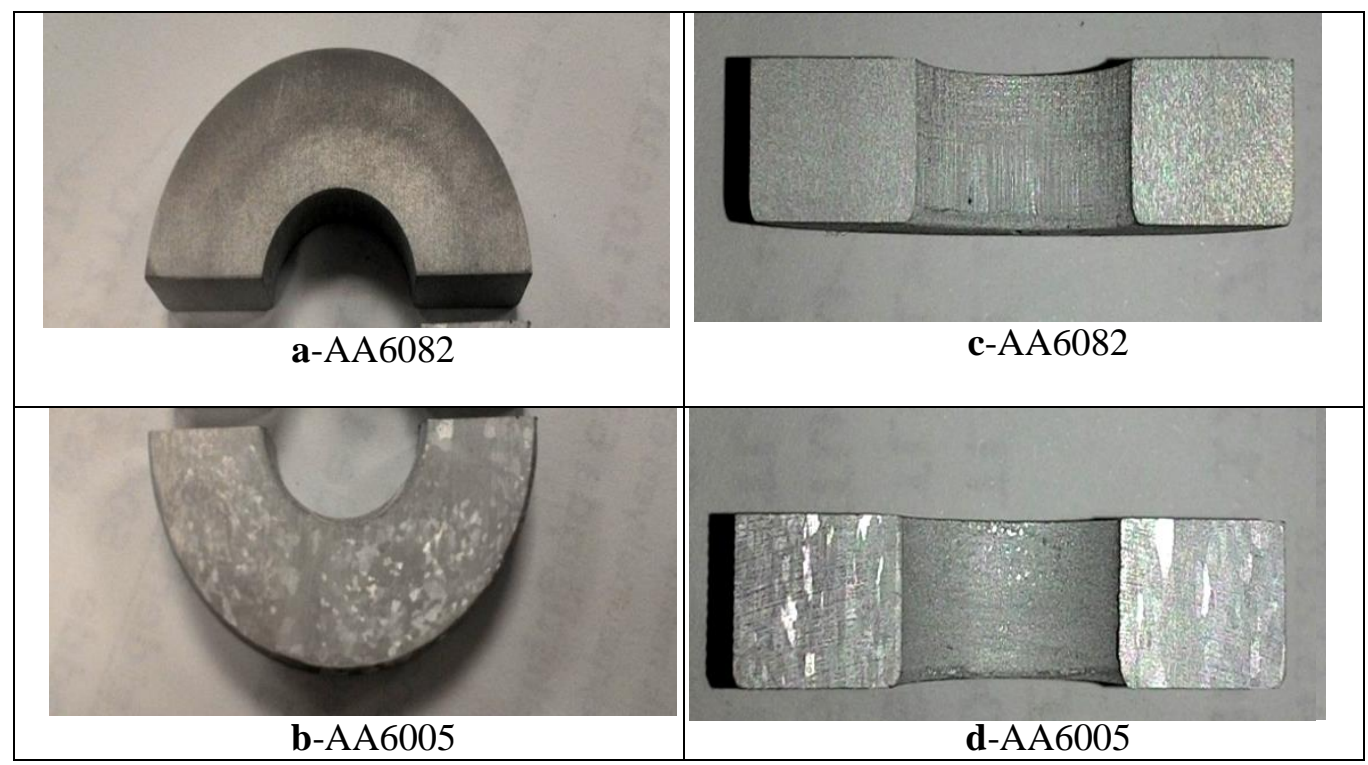

Figure 2.a-Macrostructure images of horizontal sections for AA6082 b- Macrostructure images of horizontal sections for AA6005 cMacrostructure images of vertical sections for AA6082 d-Macrostructure images of vertical sections for AA6005 


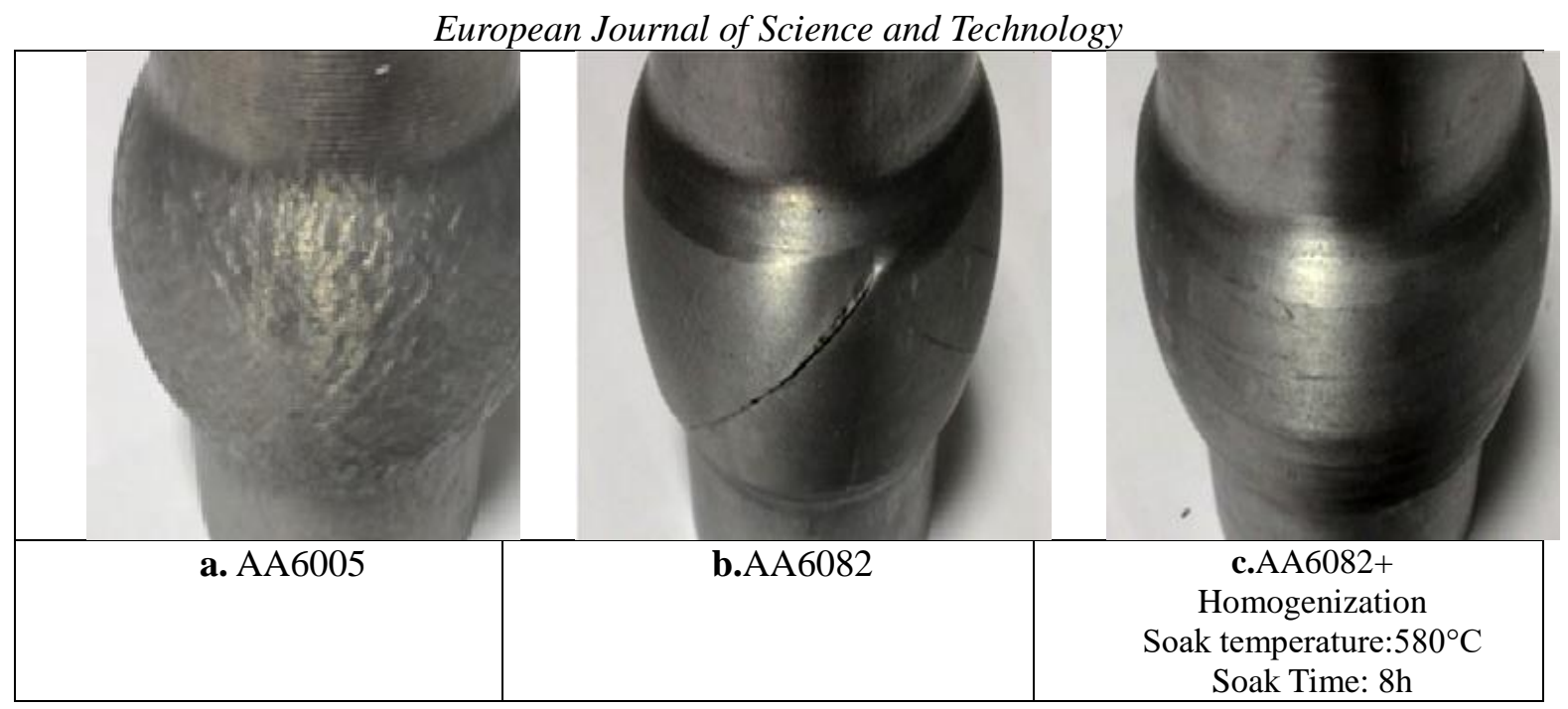

Fig 3. Macrostructure features of samples after cold forming process (a. AA6005, b. AA6082, c. AA6082+homogenization )

\section{Results and Discussion}

An experimental study was conducted to solve an industrial problem of cold forming. It is very clearly seen that thermomechanical applications highly effected on wrought alloy especially $6 \mathrm{XXX}$ series. During extrusion forming, fibers are formed in the profile in the direction of extrusion as seen in Fig1. It has been observed that the coarseness of these fibers formed in the extrusion process causes undesirable deep tears, cracks and distortion of surface when the aluminium profiles are subjected to the cold forming process. It is seen in Fig. 4 cubic intermetallic compound particles detected with XRD analysis in EN AW 6082 extrusion profile.. This intermetallic compounds consist of mainly large-size phase $\mathrm{Mg}, \mathrm{Si}, \mathrm{Mn}$ an Fe.

AA 6082 and AA 6005 are alloys which contains different percentage value of $\mathrm{Si}, \mathrm{Mg}$ and $\mathrm{Mn}$ seen in Table 1. According to the 6005 alloy standard, \% Mg can be between 0.4 and 0.6 , while experimental sample value is 0.6. The most important difference between AA6005 and AA6082 is the\% Mn value. The Mn value is 0,06 at 6005 whereas 0,61 of $\mathrm{Mn}$ at 6082 . In 6XXX alloys, manganese $(\mathrm{Mn})$ forms the fragile phase $\mathrm{AlFe}(\mathrm{Mn}) \mathrm{Si}$. These fine needle-like and dark black phases are seen in the microstructures in Figure 1. It is seen that in Fig.1 matrix alpha aluminium is more clear in the 6005 alloy, depending on the deposited secondary phases. Although there is a chemical difference between 6082 and 6005, this clear Al matrix shows that the 6005 alloy is not homogenized at a sufficient level. In Figure 1,if 6082 and homogenized 6082 are compared, it is seen that the density of secondary phases deposited in the homogenized alloy is higher. This condition can be explained by the matrix that becomes a supersaturated solution by homogenization. Generally homogenization practice used for AA 6082 alloy is to hold this at a temperature between $540^{\circ} \mathrm{C}$ and $580^{\circ} \mathrm{C}$ for up to $8 \mathrm{~h}$. One of the DSC schematic that for alloy AA6082, is shown in Fig. 5. First exothermic peaks are related with $\mathrm{Mg}$-Si piles. In this way lowest solutionizing point in the samples was indicated. $\beta$ $\mathrm{Mg} 2 \mathrm{Si}$ phases are started the solutionizing about $450^{\circ} \mathrm{C}$ at the initial of endothermic peak as seen in Fig.5. Homogenization temperatures are determinate by solidus temperature of $\mathrm{Al}$ $\operatorname{MgSi}(\mathrm{Mn})$ aluminium alloys. The amount of precipitated phases decreased with relatively high temperature heat treatment on AA6082 was observed. In this way, the transformation of $\beta \rightarrow \alpha$ phases takes place completely in AA6082.The phase transformation starts at a lower temperature in 6082 than in 6005 in Ref.[10]

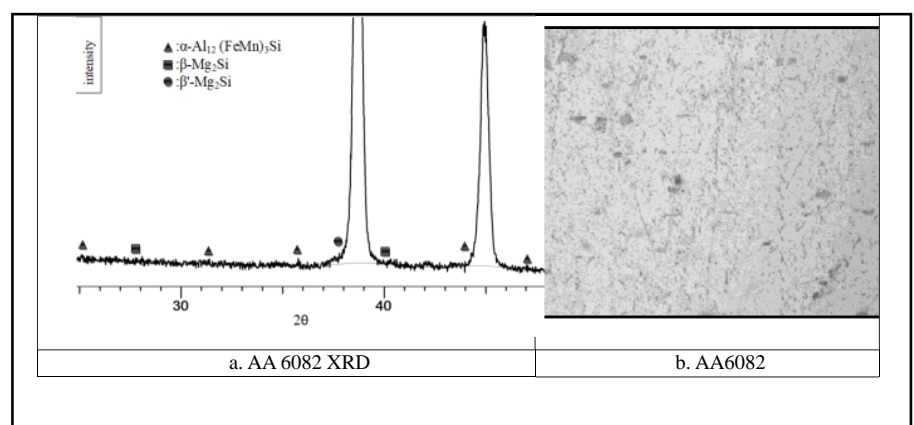

Fig 4 . a.XRD spectrum of AA 6082 sample b.Microstructure of AA 6082 sample

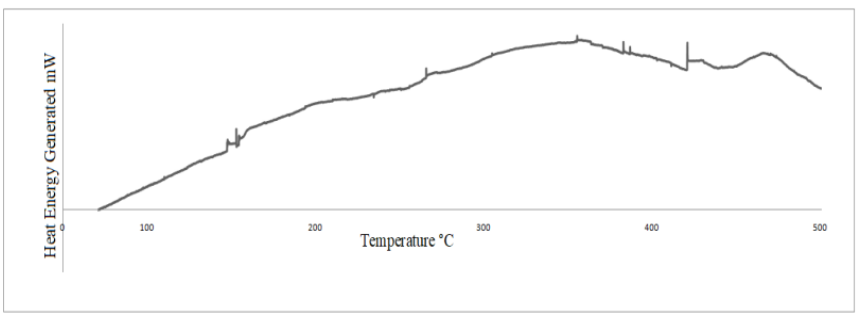

Fig 5. DSC Trace for AA6082 samples

\section{Conclusions and Recommendations}

Macro structures of AA6005 alloy and AA6082 alloy for 2 different axes is shown in Figures $2 \mathrm{a}$ and $2 \mathrm{~b}$. Extremely coarse grains is seen in the AA6005 alloy due to thermo-mechanical effects. This indicates that there is not enough homogenization to the AA6005 alloy. In the production, AA6005 extruded alloys with $36 \mathrm{HB}$ hardness are currently used and as a result of the cold forming disruption occurs on the material surface. It has 
been detected, the AA6005 alloys are not suitable for homogenization due to the grain coarsening mechanism and low hardness values. AA6082 alloys with $98 \mathrm{HB}$ hardness are also broken during cold forming. This circumstances creates a problem in terms of usage and workability. High forces are needed to cold forming process. When the 6082 alloy was homogenized not only hardness was reduced but also phase transformations within the structure were achieved. No damage and no distortion was observed on the surface of the materials formed after the homogenization heat treatment. In cold forming, for easy and suitable forming of 6XXX alloys, homogenization heat treatment should be done at temperatures and times determined specifically for the each alloy. The transformation of $\beta$-AlFeSi phases into $\alpha$-AlFeSi phase by homogenization process directly affects the cold forming ability of the AA6082 alloy.

\section{Acknowledge}

"The named authors have no conflict of interest, financial or otherwise."

\section{References}

[1] Standart Specification for Aluminium Alloy Extruded Bars, Rods, Wire, Profiles and Tubes. ASTM, Designation: B221M-12a

[2] Zhouli $\mathrm{Xu}$, Huijuan $\mathrm{Ma}$, Ning Zhao, and Zhili $\mathrm{Hu}$, Investigation on Compressive Formability and Microstructure Evolution of 6082-T6 Aluminum Alloy, J. of Metals, 10, 469-480, (2020)

[3]Saha Pradip K., Aluminium extrusion technology, Materials Park, OH 44073-0002, ISBN: 0-87170-644-X, pp(136-138), (2000)

[4]Birol Y., The effect of homogenization practice on the microstructure of AA6063 billets, Journal of Materials Processing Technology, 148(2):250-258, (2004)

[5] Beatty E.C., Proceedings of the First International Aluminium Extrusion Technology Seminar, Paper no. 10, Aluminium Association, Washington, DC, 1969.

[6] Mrówka-Nowotnik, G., Sieniawski, J., Wierzbińska, M.. Intermetallic phase particles in 6082 aluminium alloy, Archives of Materials Science and Engineering 282, 69-76, (2007).

[7] Kuijpers N.C.W., Tirel J., Hanlon, Zwaag D.N. S., Quantification of the evolution of the 3D intermetallic structure in a 6005A aluminium alloy during a homogenisation treatment, Materials Characterization, 48 pp. 379-392, (2002)

[8]T. Smith, Reilly K. O', Kumar S., I. Stone, Influence of Grain-Refiner Addition on the Morphology of Fe-Bearing Intermetallics in a Semi-Solid Processed Al-Mg-Si Alloy, Metallurgical and Materials Transactions., 44A, pp. 48664871, (2013)

[9] Dons A.L., The Alstruc homogenization model for industrial aluminum alloys, Journal of Light Metals., 1 pp. 133-149, (2001)

[10] Bayata N., Cieslarb M., In-situ study of phase transformations during homogenization of 6005 and $6082 \mathrm{Al}$ alloys, Journal of Alloys and Compounds, 725, 25, Pp 504509, (2017)

[11] M. Çiğdem and Y. Erarslan "The Effect of Mould Lubrication on The Surface And Subsurface Quality of Semi
Continiously DC cast Al-6063 alloy billets" Practical Metallography, 34, 11, 555-573,(1997)

[12] Yucel B. The effect of processing and Mn content on the T5and T6 properties of AA6082 Profiles, Journal of Materials Processing Technology 173, 84-91,(2006)

[13] J. Van Rijkom, W.S. Miller, Proc. 6th International Aluminium Extrusion Technology Seminar, Vol. 1, Aluminium Association, , 149-155 Washington, DC, (1996) 